\title{
伝達マトリクス法による建築構造システムの局所的減衰評価に関する研究 LOCAL DAMPING ESTIMATION OF BUILDING STRUCTURAL SYSTEMS BY MEANS OF TRANSFER MATRIX TECHNIQUE
}

\author{
山田聖 治*, 西谷 章**
}

Seiji YAMADA and Akira NISHITANI

\begin{abstract}
In estimating the motion characteristics of a building, the modal decomposition technique is frequently employed. However, it doesn't fit to the estimation of those of subsystems in a building structural system. This paper focuses on the damping estimation of such subsystems. By means of the transfer matrix method, a structure is divided into a number of substructures, which then are to be identified. A standing wave arisen inside a structure is decomposed into forward and backward moving waves in virtue of the wave propagation theory. Then, a local damping factor is estimated from the forward moving wave. This damping factor is regarding the local information, which the modal analysis cannot deal with. To demonstrate the validity of the proposed method, numerical simulations are conducted with respect to four-story building models subjected to random white noise excitations.
\end{abstract}

Keywords : Local damping, Wave propagation, Transfer matrix, Random excitations, Structural health monitoring 局所的减衰，波動伝播，伝達マトリクス，ランダム加振，構造ヘルスモニタリング

\section{1 はじめに}

振動解析の一手法に伝達マトリクス法 ${ }^{3,4)}$ がある。伝達マトリ クス法では, 質点・剛性・减衰などの構造システムの構成要素をサ ブシステムに分け，サブシステム相互の関係をマトリクス表記す る。この方法は, 任意の 2 点間の関係をマトリクスによって表すこ とができるので，モード解析 ${ }^{5)}$ では困難な構造物の局所的な解析 に適用が可能であり，振動制御にも利用されている ${ }^{6)}$ 。

建築構造物の振動は，地震・風などの外乱が作用することにより 発生する。振動を発生させる原因となる外乱は，波動として建築構 造物に付加され，構造物内部を伝播する ${ }^{7-10)}$ 。よって，外乱を波 動として扱い，構造物内部の波動の伝播特性を認識することは，構 造システムの制御 ${ }^{11)}$ において非常に有用となる。

以上の観点から，本論文では，波動理論と伝達マトリクス法を用 いて，建築構造物の局所的减衰を評価することを目的としている。 波動理論と伝達マトリクス法を構造物に適用した論文としては, 福 和ら ${ }^{12,13)}$ のものがある。これらの論文では，伝達マトリクス法 の適用に適した線状周期構造物を扱い，離散解析時の最適な質量 行列作成法について検討している。本研究においては, 建築構造シ
ステムにおける局所的な減衰を示す指標として「層間伝達减衰比」 を導入する。「層間伝達減衰比」は，伝達マトリクス法と波動理論 をもとに建築構造物に発生する定常波を進行波と後退波に分解し たうえで, ある層と次の層の進行波の振幅比から算出されるエネル ギー損失率を 1 自由度系の減衰自由振動におけるエネルギー損失 率に換算して決定される。

提案する「層間伝達減衰比」は，ひとつの層から次の層への減衰 を表しているので, 局所的な減衰を的確に判断することができる。 また,「層間伝達减衰比」と周波数の関係から，各モードの粘性減 衰比間の関係を明らかにすることもできる。本論文では,「層間伝 達减衰比」により建筑構造システムの局所的な減衰状況の把握が可 能であることを示す。この指標をもとにすることで, 制振効果の確 認や構造ヘルスモニタリングへの将来的な応用も期待できる。

\section{2 層間伝達減衰比の定式化}

\section{1 伝達マトリクスによる構造物の分離}

伝達マトリクスを用いて，建築構造物をサブシステムに分離する が, 本研究ではサブシステムとして層を採用し,「層間伝達减衰比」 を定式化する。 $(i-1)$ 階床の上部から $i$ 階床の上部までを $i$ 層と

\footnotetext{
本論文は，日本建築学会大会で発表した内容(文献 $[1,2]$ )をもとに，あらたな計算により加筆・修正を加えたものである。

* 早稲田大学理工学部建築学科 助手. 修士 (工学) Research Assoc., Dept. of Architecture, Waseda Univ., M. Eng.

** 早稲田大学理工学部建築学科 教授. Ph. D. · 工博 
する。Fig.1に示す多層のせん断型モデルが周波数 $f(\mathrm{~Hz})$ で振動し ているとする。 $i$ 層の状態量べクトル $\mathbf{Z}_{i}$ として変位 $x_{i}$ とそれに対 忘するせん断力 $Q_{i}$ を採用する。

Fig.2のように, $i$ 層の質点 $m_{i}$ をとりだせば，質点上部の状態 量 $\left[\begin{array}{ll}x_{i}^{U} & Q_{i}^{U}\end{array}\right]^{T}$ と質点下部の状態量 $\left[x_{i}^{L} ， Q_{i}^{L}\right]^{T}$ の関係は, $x_{i}^{U}=x_{i}^{L}$ および

$$
\begin{aligned}
Q_{i}^{U} & =-m_{i} \omega^{2} x_{i}^{L}+Q_{i}^{L} \\
\text { ただし, } \quad \omega & =2 \pi f
\end{aligned}
$$

であることから，以下のようになる。

$$
\left[\begin{array}{c}
x_{i}^{U} \\
Q_{i}^{U}
\end{array}\right]=\left[\begin{array}{cc}
1 & 0 \\
-m_{i} \omega^{2} & 1
\end{array}\right]\left[\begin{array}{c}
x_{i}^{L} \\
Q_{i}^{L}
\end{array}\right]
$$

これが質点 $m_{i}$ の下部の状態から上部の状態への伝達を表す関係式 であり, 式 (2) 右辺の係数マトリクスが格点マトリクスとなる。

次に, Fig.3のように， $i$ 層をとりだして考えれば, $Q_{i}^{L}=Q_{i-1}^{U}$ であり，Kelvin 型モデルを仮定すると変位の関係式は，

$$
\begin{aligned}
x_{i}^{L} & =x_{i-1}^{U}+\frac{1}{k_{i}+j c_{i} \omega} Q_{i-1}^{U} \\
\text { ただし, } \quad j & =\sqrt{-1}
\end{aligned}
$$

となって，以下の関俰が導かれる。

$$
\left[\begin{array}{c}
x_{i}^{L} \\
Q_{i}^{L}
\end{array}\right]=\left[\begin{array}{cc}
1 & \frac{1}{k_{i}+j c_{i} \omega} \\
0 & 1
\end{array}\right]\left[\begin{array}{c}
x_{i-1}^{U} \\
Q_{i-1}^{U}
\end{array}\right]
$$

式 (4) が Kelvin 型モデルを仮定したときの質点 $m_{i-1}$ の上部の状 態から質点 $m_{i}$ の下部の状態への伝達を表す関俰式であり, 式 (4) 右辺の係数マトリクスが格間マトリクスである。

式 (2);(4) より, 質点 $m_{i-1}$ の上部の状態から質点 $m_{i}$ の上部の 状態への伝達マトリクス $\mathrm{U}_{i}$ は, 格点マトリクスと格間マトリクス の積で表され，次式のようになる。

$$
\left[\begin{array}{c}
x_{i}^{U} \\
Q_{i}^{U}
\end{array}\right]=\left[\begin{array}{cc}
1 & \frac{1}{k_{i}+j c_{i} \omega} \\
-m_{i} \omega^{2} & 1-\frac{m_{i} \omega^{2}}{k_{i}+j c_{i} \omega}
\end{array}\right]\left[\begin{array}{c}
x_{i-1}^{U} \\
Q_{i-1}^{U}
\end{array}\right]
$$

ただし, 式 (5) は $i$ 層に外力が働いていない場合である。 $i$ 層に外 カが存在する場合, 式 (1) は,

$$
Q_{n}^{U}=-m_{n} \omega^{2} x_{n}^{L}+Q_{n}^{L}-f_{i}
$$

となって, $i$ 層の伝達マトリクスのは以下のようになる。

$$
\left[\begin{array}{c}
x_{i}^{U} \\
Q_{i}^{U} \\
1
\end{array}\right]=\left[\begin{array}{ccc}
1 & \frac{1}{k_{i}+j c_{i} \omega} & 0 \\
-m_{i} \omega^{2} & 1-\frac{m_{i} \omega^{2}}{k_{i}+j c_{i} \omega} & -f_{i} \\
0 & 0 & 1
\end{array}\right]\left[\begin{array}{c}
x_{i-1}^{U} \\
Q_{i-1}^{U} \\
1
\end{array}\right]
$$

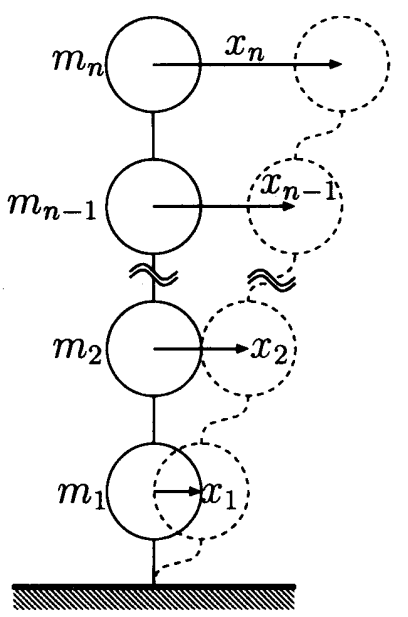

Fig. 1 Shear structure model representing a multi-story building

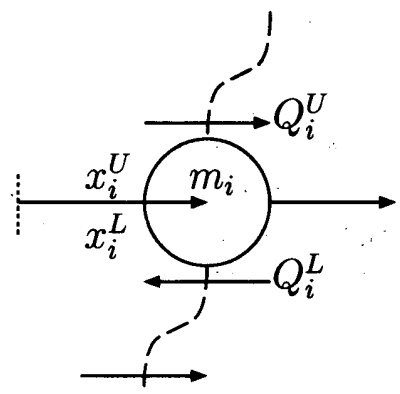

Fig. 2 Displacements and shear forces with respect to the mass $m_{i}$

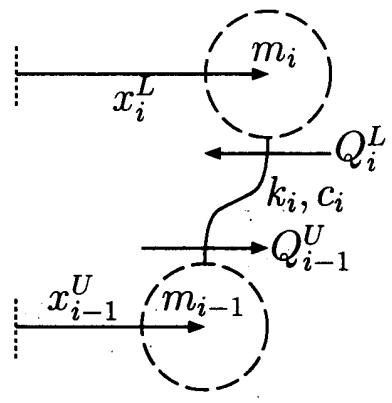

Fig. 3 Displacements and shear forces between the masses $m_{i}$ and $m_{i-1}$

$$
\left[\begin{array}{c}
x_{i}^{L} \\
Q_{i}^{L}
\end{array}\right]=\left[\begin{array}{cc}
1 & \frac{1}{k_{i}}+\frac{1}{j c_{i} \omega} \\
0 & 1
\end{array}\right]\left[\begin{array}{l}
x_{i-1}^{U} \\
Q_{i-1}^{U}
\end{array}\right]
$$

となる。式 (8) が Maxwell 型モデルを仮定したときの質点 $m_{i-1}$ の上部の状態から質点 $m_{i}$.の下部の状態への伝達を表す関係式で ある。

式 $(2),(8)$ より, Maxwell 型モデルの伝達マトリクス $\mathbf{U}_{i}$ は, 次 式のようになる。

$\left[\begin{array}{c}x_{i}^{U} \\ Q_{i}^{U}\end{array}\right]=\left[\begin{array}{cc}1 & \frac{1}{k_{i}}+\frac{1}{j c_{i} \omega} \\ -m_{i} \omega^{2} & 1-\left(\frac{m_{i} \omega^{2}}{k_{i}}+\frac{m_{i} \omega^{2}}{j c_{i} \omega}\right)\end{array}\right]\left[\begin{array}{l}x_{i-1}^{U} \\ Q_{i-1}^{U}\end{array}\right]$

また, Maxwell 型モデルを仮定すると式 (4) は, 
さらに, $i$ 層に外力が存在する場合の伝達マトリクスのは以下のよ うになる。

$$
\begin{aligned}
& {\left[\begin{array}{c}
x_{i}^{U} \\
Q_{i}^{U} \\
1
\end{array}\right]} \\
& =\left[\begin{array}{ccc}
1 & \frac{1}{k_{i}}+\frac{1}{j c_{i} \omega} & 0 \\
-m_{i} \omega^{2} & 1-\left(\frac{m_{i} \omega^{2}}{k_{i}}+\frac{m_{i} \omega^{2}}{j c_{i} \omega}\right) & -f_{i} \\
0 & 0 & 1
\end{array}\right]\left[\begin{array}{c}
x_{i-1}^{U} \\
Q_{i-1}^{U} \\
1
\end{array}\right]
\end{aligned}
$$

式 (5),(7) あるいは式 (9),(10) の関係より，各層の状態べクトル から Kelvin 型, Maxwell 型モデルに対応する各層の伝達マトリ クスが計算できる。層間を伝播する波の関係を求めるために，次節 において, 波動理論を適用し,「層間伝達減衰比」を定式化する。

\section{2 層間伝達減衰比の定式化}

構造物に作用する力は，波動として構造物内部を伝播する。伝播 する波は，境界に達すると，境界条件に态じて通過する進行波と反 射する後退波に分かれる。強制加振が正弦波であれば，進行波と後 退波は互いに干涉しあい, 定常波を生じる。つまり，正弦波加振さ れた構造物の内部では, 常に進行波と後退波が存在している。これ らの波は，構造物内部を伝播する波である。

$i$ 層の進行波と後退波の複素振幅 $w_{i}^{+}, w_{i}^{-}$を要素とする波動べク トルを $\mathbf{W}_{i}$ と表す。このとき $(i-1)$ 層の波動べクトル $\mathbf{W}_{i-1}$ と $i$ 層の波動べクトル $\mathbf{W}_{i}$ の関倸は, 波動の伝達マトリクス $\boldsymbol{\Lambda}_{i}$ を介 して,

$$
\mathbf{W}_{i}=\mathbf{\Lambda}_{i} \mathbf{W}_{i-1}
$$

となる。波動の伝達マトリクス $\boldsymbol{\Lambda}_{i}$ を, 状態量ベクトル $\mathbf{Z}_{i}$ を波動 ベクトル $\mathbf{W}_{i}$ に変換するマトリクス $\boldsymbol{\Gamma}$ を用いて以下のように表す。

$$
\boldsymbol{\Lambda}_{i}=\Gamma \mathbf{U}_{i} \boldsymbol{\Gamma}^{-1}
$$

ただし, $\mathrm{U}_{i}$ は $(i-1)$ 層から $i$ 層への伝達マトリクスであり, Kelvin 型モデルでは式 (5),(7), Maxwell 型モデルでは式 (9),(10) とな る。 $\Lambda_{i}$ の対角成分を $\lambda_{i}, \lambda_{i}, \Gamma$ の列成分を $\gamma_{1}, \gamma_{2}$ とすると,

$$
\left[\begin{array}{cc}
\lambda_{i} & 0 \\
0 & \dot{\lambda}_{i}
\end{array}\right]=\left[\begin{array}{ll}
\gamma_{1} & \gamma_{2}
\end{array}\right] \mathbf{U}_{i}\left[\begin{array}{ll}
\gamma_{1} & \gamma_{2}
\end{array}\right]^{-1}
$$

であり, 結局,

$$
\left\{\begin{array}{l}
\lambda_{i} \boldsymbol{\gamma}_{1}=\boldsymbol{\gamma}_{1} \mathbf{U}_{i} \\
\dot{\lambda}_{i} \boldsymbol{\gamma}_{2}=\boldsymbol{\gamma}_{2} \mathbf{U}_{i}
\end{array}\right.
$$

と書きかえることができる。これは, 行列 $\mathbf{U}_{i}$ の固有値問題であ る。したがって, 式(11) は,

$$
\left[\begin{array}{c}
w_{i}^{+} \\
w_{i}^{-}
\end{array}\right]=\left[\begin{array}{cc}
e^{(-\alpha-j \beta)} & 0 \\
0 & e^{(\alpha+j \beta)}
\end{array}\right]\left[\begin{array}{l}
w_{i-1}^{+} \\
w_{i-1}^{-}
\end{array}\right]
$$

ここに,

$$
\left\{\begin{array}{l}
\alpha=\operatorname{Re}\left(\ln \lambda_{i}\right) \\
\beta=\operatorname{Im}\left(\ln \lambda_{i}\right)
\end{array}\right.
$$

式 (15) は，層から層へ波が伝達する関俰を表現しており，進行波 と後退波の関係は独立となる。以下では進行波についてのみ検討
Table 1 Building models for numerical examples

\begin{tabular}{c|c|c|c|c|c|c}
\hline & & \multicolumn{5}{|c}{ Model } \\
\cline { 3 - 7 } & story & \multicolumn{1}{|c|}{ K } & \multicolumn{1}{c}{ K1 } & K2 & C1 & C2 \\
\hline$m[\mathrm{~kg}]$ & $1-4$ & 2.6 & \multicolumn{1}{c}{2.6} & \multicolumn{1}{c}{2.6} & 2.6 & 2.6 \\
\hline & 4 & 37.5 & 37.5 & 37.5 & 39.375 & 41.25 \\
$c_{i}$ & 3 & 60.0 & 60.0 & 60.0 & 60.0 & 60.0 \\
$(\mathrm{~N} /(\mathrm{m} / \mathrm{s}))$ & 2 & 82.5 & 82.5 & 82.5 & 86.625 & 90.75 \\
& 1 & 105.0 & 105.0 & 105.0 & 105.0 & 105.0 \\
\hline & 4 & 9000 & 8100 & 9000 & 9000 & 9000 \\
$k_{i}$ & 3 & 9000 & 9000 & 9000 & 9000 & 9000 \\
$(\mathrm{~N} / \mathrm{m})$ & 2 & 9000 & 8100 & 8100 & 9000 & 9000 \\
& 1 & 9000 & 9000 & 9000 & 9000 & 9000 \\
\hline
\end{tabular}

し,「層間伝達减衰比」を定義する。式 (15)において, $w_{i}^{+}$は複素 振幅であり, 両辺に $e^{j \omega t}$ を乗じて, 進行波のみを取り出すと,

$$
w_{i}^{+} e^{j \omega t}=e^{(-\alpha-j \beta)} w_{i-1}^{+} e^{j \omega t}
$$

と表現される。式 (17) に示した進行波のエネルギー消費量を 1 質 点系における減衰自由振動のエネルギー消費量と対応させる。1 質 点减衰系モデルに初期変位を与えた時の減衰自由振動において，エ ネルギー損失率 $\psi_{f}$ は以下のように表される。

$$
\psi_{f}=1-\exp \left(\frac{-4 \pi \zeta_{m}}{\sqrt{1-\zeta_{m}^{2}}}\right)
$$

ここに, $\zeta_{m}$ は粘性隇衰比であり，時間に関する減衰率である。一 方, 進行波のエネルギ一損失率 $\psi_{w}$ は, 進行波の式 (17) から次の ようになる。

$$
\psi_{w}=1-\exp \left(\frac{-4 \pi \alpha}{\beta}\right)
$$

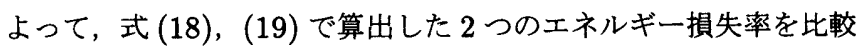
し, 進行波の減衰率 $\zeta_{p}$ を $\zeta_{m}$ に換算すると,

$$
\zeta_{p}=\frac{\frac{\alpha}{\beta}}{\sqrt{1+\left(\frac{\alpha}{\beta}\right)^{2}}}
$$

式 (20) が本論文で提案する「層間伝達减衰比」である。本指標は, 入力正弦波の周波数によって值が変化するので, 対象構造物に印加 する周波数ごとに「層間伝達減衰比」を算出できる。

\section{3 シミュレーションによる確認 \\ 3.1 隇衰型による層間伝達隇衰比の差異}

本論文で提案する層間伝達减衰比から, 各モードの粘性減衰比間 の関係が明らかとなることを確認するために, Table 1に示す 4 層 モデル Model A に対して, Kelvin 型と Maxwell 型を仮定した場 合の 2 層と 4 層の層間伝達減衰比の佔を Figs.4,5に示す。

これらの図からわかるように, 層間伝達減衰比は周波数に対し て, Kelvin 型では增加し, Maxwell 型では減少する。このように, 層間伝達减衰比と周波数の関係から, 各モードの粘性減衰比間の関 係を明らかにすることができる。ただし，一般の構造物では，减衰 の型が一つで表現できるとは限らず，どのようなタイプの減衰が支 配的であるかを示す指標として用いることになる。 

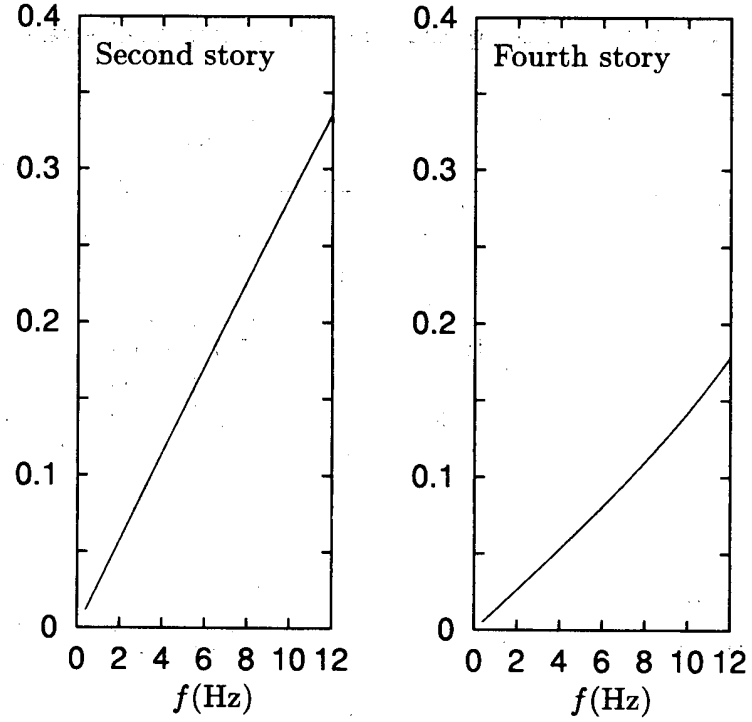

Fig. 4 Local equivalent damping ratios based on Kelvin model
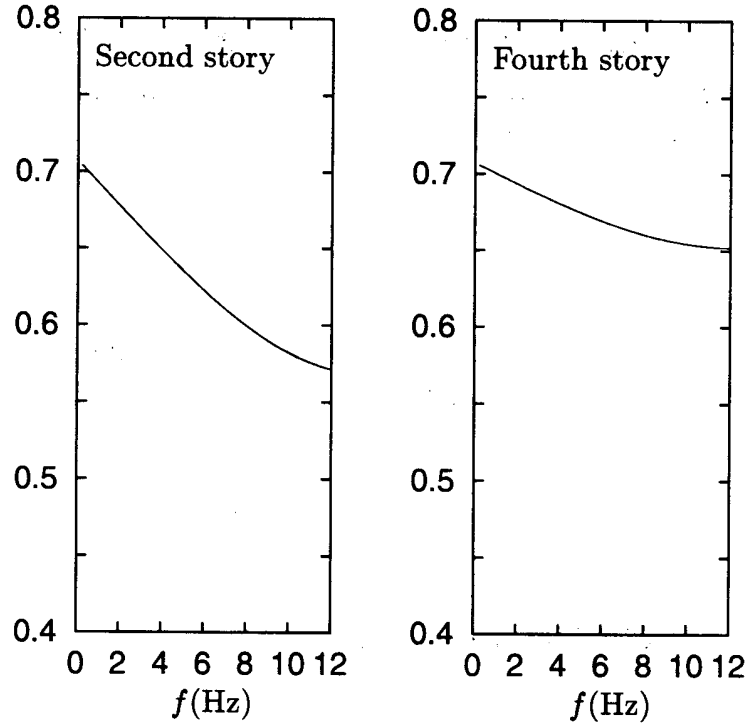

Fig. 5 Local equivalent damping ratios based on Maxwell model

\section{2 層間伝達減衰比による局所的減衰状況の把握}

次に, 層間伝達減衰比によって局所的な減衰状況が推定できるこ とを確認するために, Table 1に示す 4 層モデルを Kelvin 型と仮 定して, パラメータ変動による層間伝達減衰比の増減を理論值に よって比較する。

Model A を基本のモデルとし, Model A からパラメータが変動 したモデルとして $\mathrm{K} 1 ， \mathrm{~K} 2 ， \mathrm{C} 1 ， \mathrm{C} 2$ の 4 つのモデルを設定する。 Model K1，K2 は剛性を堿少させたモデルであり, Model A と比 べそれぞれ 2,4 層および 2 層のみの $k$ を $10 \%$ 减少させている。ま た, Model C1, C2 は減衰を增加させたモデルであり, Model A と比べそれぞれ 2,4 層の $c$ を $5 \%$ および $10 \%$ 增加させている。

Model K1，K2，C1，C2 それぞれのモデルに対して求めた層 間伝達减衰比の 2 層と 4 層について，Model A のそれと比較した 図を Figs.6〜 9に示す。これらの図において，実線で示されたもの が Model A, 点線で示されたものが各モデルである。以上の図か ら, 剛性低下あるいは减衰増加のどちらの場合も, 層間伝達减衰比
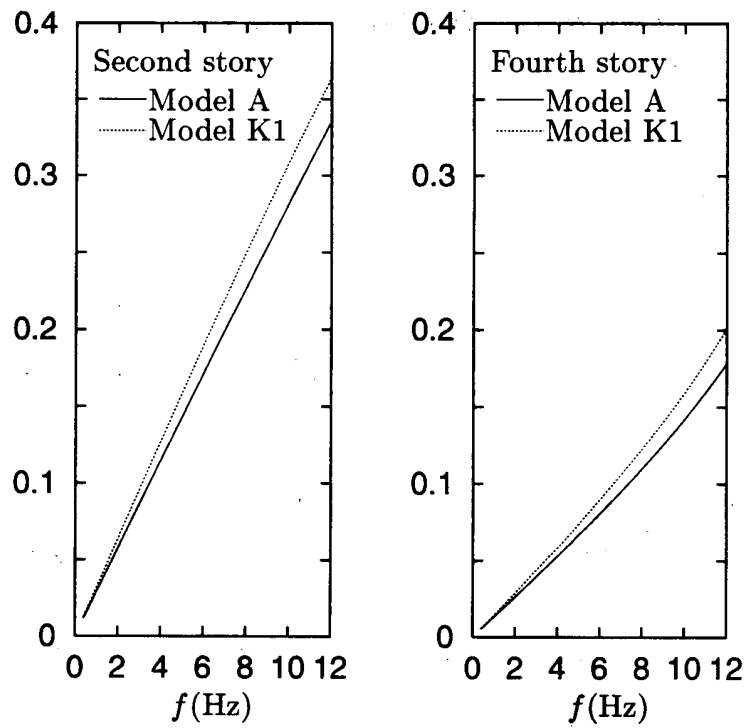

Fig. 6 Comparison of local equivalent damping ràtios between Models A and K1
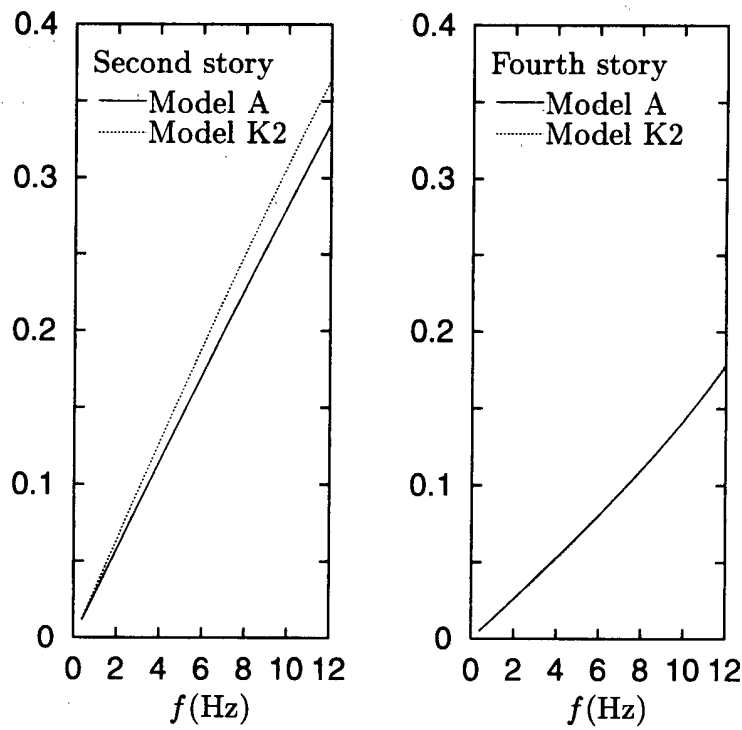

Fig. 7 Comparison of local equivalent damping ratios between Models A and K2
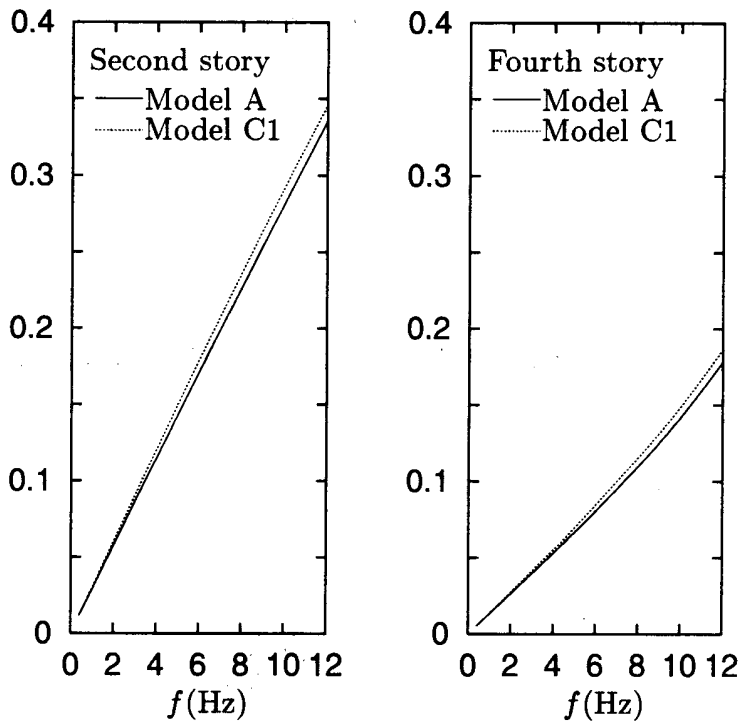

Fig. 8 Comparison of local equivalent damping ratios between Models $A$ and $C 1$ 

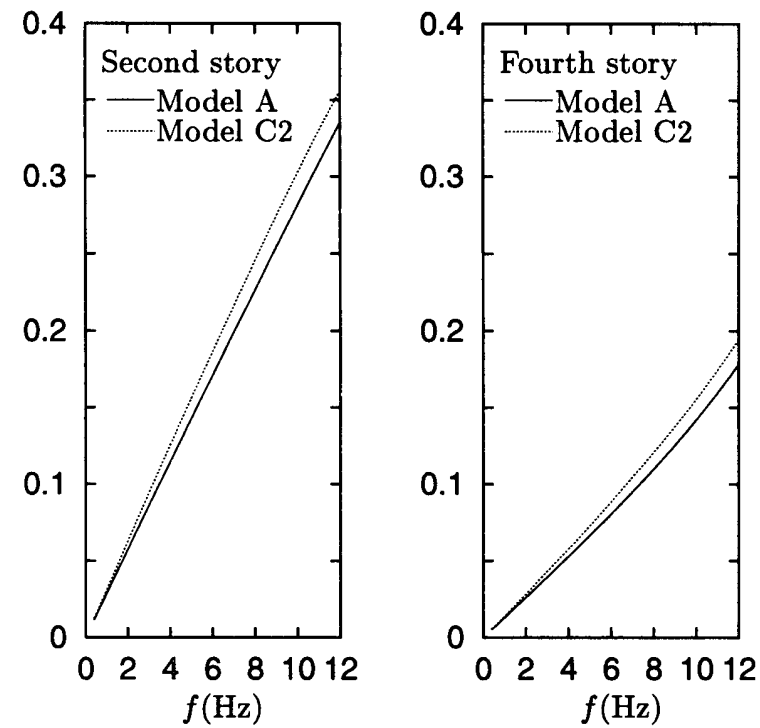

Fig. 9 Comparison of local equivalent damping ratios between Models $A$ and $\mathrm{C2}$

Table 2 Natural frequencies and damping ratios of model buildings

\begin{tabular}{c|c|r|r|r|r|r}
\hline & & \multicolumn{6}{|c}{ Model } \\
\cline { 3 - 7 } & Mode & \multicolumn{1}{|c|}{ A } & \multicolumn{1}{|c|}{ K1 } & \multicolumn{1}{c}{ K2 } & \multicolumn{1}{c}{ C1 } & \multicolumn{1}{c}{ C2 } \\
\hline \multirow{4}{*}{$f$} & 1 & 3.2 & 3.2 & 3.2 & 3.2 & 3.2 \\
$(\mathrm{~Hz})$ & 2 & 9.3 & 9.1 & 9.3 & 9.3 & 9.2 \\
& 3 & 14.0 & 14.0 & 14.0 & 14.0 & 14.0 \\
& 4 & 15.0 & 14.0 & 14.0 & 15.0 & 15.0 \\
\hline \multirow{4}{*}{$\zeta$} & 1 & 0.10 & 0.099 & 0.10 & 0.099 & 0.10 \\
& 2 & 0.23 & 0.22 & 0.22 & 0.23 & 0.23 \\
& 3 & 0.32 & 0.35 & 0.34 & 0.33 & 0.34 \\
& 4 & 0.48 & 0.50 & 0.49 & 0.51 & 0.53 \\
\hline
\end{tabular}

が増加することがわかる。そして, Figs.6,7からパラメータ変動籄 所のみの層間伝達减衰比が変化すること, Figs.8,9から減衰のパラ メータ変動量の大小に応じて層間伝達減衰比の変化量が異なること がわかる。また, 図示していないが, パラメータ変動を設定してい ない 1 層と 3 層では, Model A とそれぞれのモデルの層間伝達減 衰比が完全に一致している。さらに，㴊性増加あるいは減衰低下を 仮定したモデルでは層間伝達减衰比は減少し, 剛性のパラメータ変 動量を変化させたモデルと減衰のパラメータ変動箇所の数を変え たモデルにおいても，前述と同様の傾向が得られた。つまり，パラ メータ変動箇所のみの層間伝達堿衰比が, パラメータ変動の量に応 じて変化することがわかる。

ただし，現状では，層間伝達减衰比のみから減衰・剛性のどちら (あるいはその両方) に変化が生じたかを判断するのは必ずしも簡 単ではない。しかし， 3.1 で示したように，層間伝達减哀比により あらかじめどのようなタイプの減衰が支配的であるかを特定するこ とは可能である。したがって, 補遗に示す関係より减衰・剛性の值 を算出することができ, 建築構造物の振動解析・制振システム設計 の指標や構造へルスモニタリングへの将来的な応用が可能になるこ とが期待できる。

Table 2に, モード解析より求めた各モードの固有振動数および 粘性減衰比を示す。Table 2において, それぞれのモデルの固有振 動数・粘性减衰比ともにModel A からのずれが見られるが，これ
らの值のみから，局所的な層の変動を特定することは困難である。 ただし，1 次のモード粘性減衰比が $10 \%$ 程度のモデルを設定して いるのは, 4 で行う 2 つのタイプの推定シミュレーションにおい て, 変位応答の層間の振幅差・位相差が与える影響を明確にするた めである。

\section{4 層間伝達減衰比の推定手法 \\ 4.1 正弦波加振による推定}

前章までで層間伝達减衰比が定式化され，その効果を確認するこ とができた。本章では，層間伝達减衰比の推定手法を検討する。層 間伝達减衰比は，定常波を進行波と後退波に分解することが前提で あるから，最上層への正弦波加振による手法を用いる。

具体的な推定手順は以下のようである。

(i) 各層の変位忘答 $x_{i}$ を観測する,

(ii) 式 (1),(6) を最上層から順次計算することで各層のせん断力 $Q_{i}$ を算出する,

(iii) 式 (5),(7) あるいは式 (9),(10) に $x_{i}, Q_{i}$ を代入することで伝 達マトリクス $U_{i}$ を決定する,

(iv) 式 (16) から $\alpha, \beta$ を計算する,

(v) 式 (20) から層間伝達減衰比を推定する。

以上の手順により，前述の Model A を Kelvin 型と仮定して層 間伝達減衰比の推定を行う。最上層に入力される正弦波は，周波数 $f(\mathrm{~Hz})$ で, 振幅 $1(\mathrm{~cm})$ の正弦波 $y=\sin (2 \pi f)$ とし，周波数 $f$ を 0 〜 $12(\mathrm{~Hz})$ まで $0.4(\mathrm{~Hz})$ ごとに変化させる。出力としては, 全ての層 の変位を計測し，サンプリング時間間隔 $\Delta t$ を $0.001(\mathrm{~s}), 0.0001(\mathrm{~s})$ の 2 種類とした。

推定された 2 層と 4 層の層間伝達減衰比と理論値を Figs. 10,11 に示す。図においては，実線で示したものが理論值、〉の印で示し たものが推定值である。これらの図から，正弦波加振による手法で は，細かいサンプリング時間間隔が必要であると判断できるが， 1 次モードの粘性減衰比が $10 \%$ のモデルに $0.0001[\mathrm{~s}]$ を用いても推 定精度にはばらつきが存在している。さらに，対象モデルの減衰 が小さい場合, 推定精度はさらに悪化する可能性がある。したがっ て，精度良くするために可能な限りサンプリング時間間隔を細かく する必要があるが，実在構造物への適用を考えると現実的な手法で はない。

\section{2 ランダム加振による推定}

4.1 で行った，せん断力の逐次計算や伝達マトリクスの推定に 正弦波加振時の変位応答を直接用いる手法では，推定精度やサンプ リング時間間隔などの観点から現実的な手法とは言い難い。これ は，変位応答の層間の振幅差・位相差が微小となるような周波数領 域では，振幅差・位相差への観測誤差の影響が大きく，これらの值 が大きく影響する層間伝達减衰比の推定值が悪化する傾向にあるか らである。

そこで，各層の変位応答 $x_{i}$ の観測值を直接推定に用いるのでは なく，得られた観測データからコンプライアンス $G(j 2 \pi f)$ を推定 した上で，4.1に示した手順 (i) におうりる各周波数の $x_{i}$ を決定す る。コンプライアンスの推定においては, ランダム (ホワイトノイ ズ) 加振とし，著者らが既報 ${ }^{14)}$ で用いたように，観測された入出力 

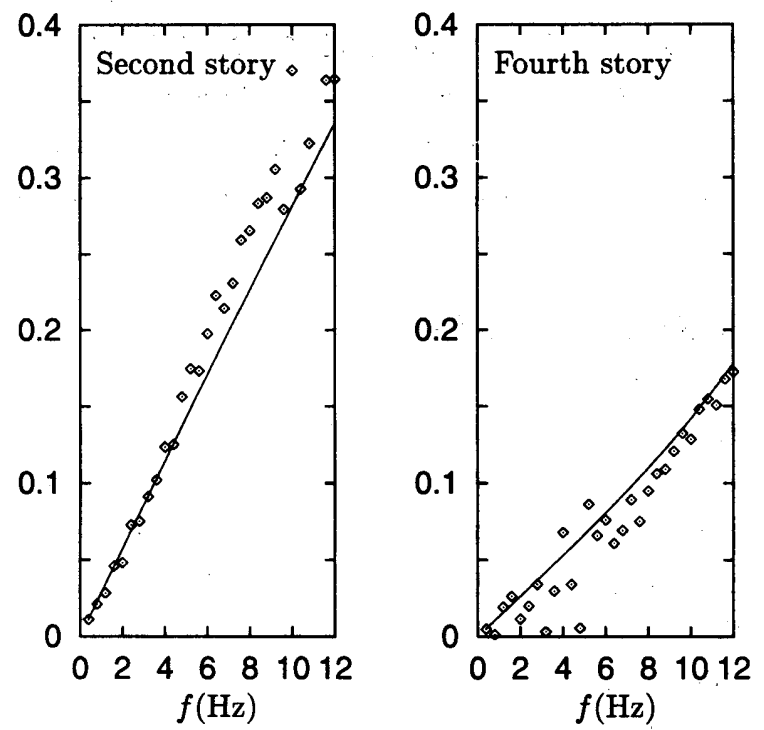

Fig. 10 Local equivalent damping ratios estimated from sinusoidal input excitations with sampling time 0.001s for Model A
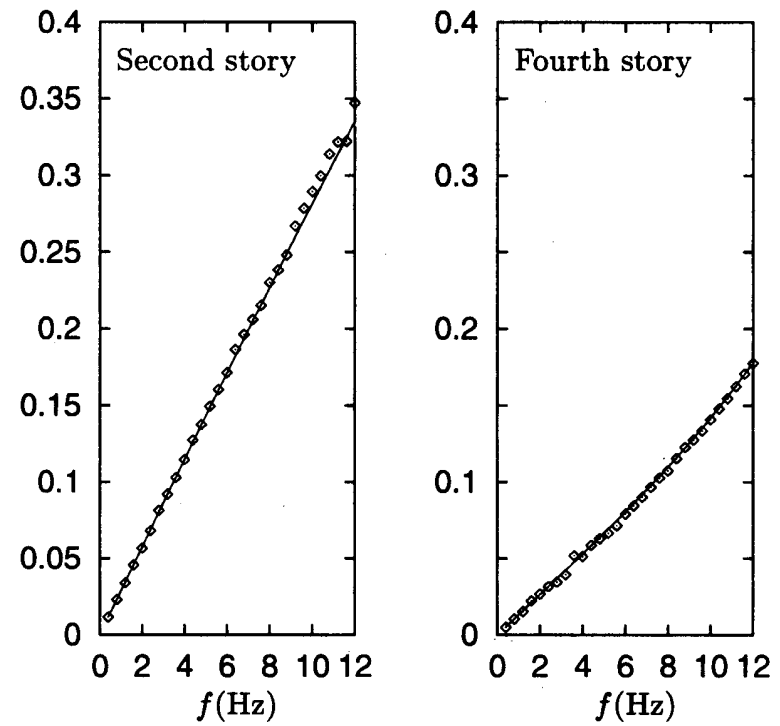

Fig. 11 Local equivalent damping ratios estimated from sinusoidal input excitations with sampling time 0.0001s for Model A
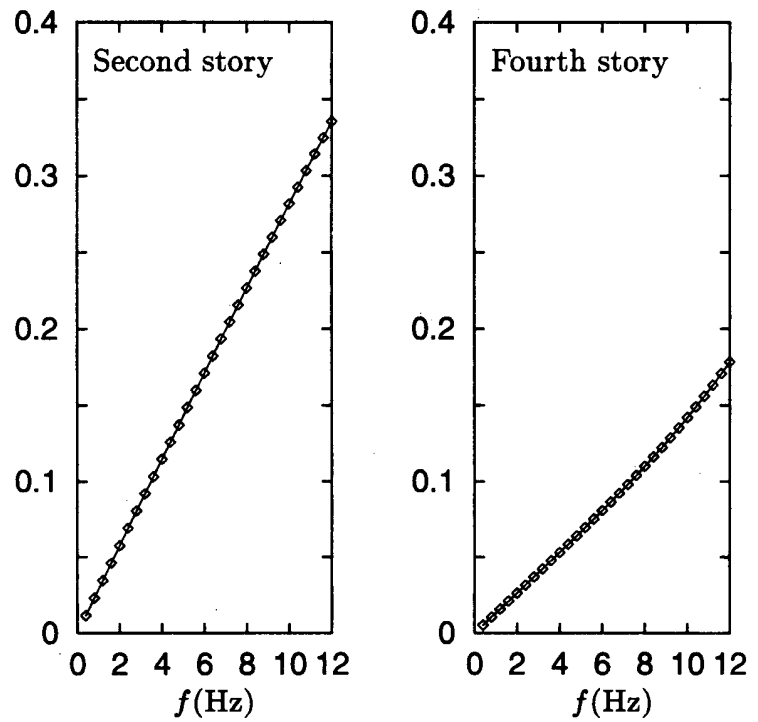

Fig. 12 Local equivalent damping ratios estimated from random input excitations with sampling time 0.01 s for Model A
データを線形回帰モデルで表現し，最小二乗法によって推定する。

$$
G(j 2 \pi f)=\frac{X(j 2 \pi f)}{F(j 2 \pi f)}
$$

ここに, $X(j 2 \pi f)$ は各層の変位応答, $F(j 2 \pi f)$ は強制入力を表し ている。 $F(j 2 \pi f)$ は，たとえば AMD を利用した加振であれば, AMD の動きと AMD の質量が既知であるとみなすことができるの で, 上式から各周波数に対する各層の複素振幅が推定できる。した がって，この推定値をもとに手順 (ii) から (v) を行うことで, 層間 伝達减衰比を推定することができる。解析にするにあたっては, 全 ての層の加速度応答を出力とし，サンプリング時間間隔を $0.01(\mathrm{~s})$, データ個数 512, 線形回帰モデルの次数を 10 次とした。得られた 2 層と 4 層の推定值と理論値との比較を Fig.12に示す。この図に おいて, 実線で示したものが各層の理論値, ১の印で示したものが 各層の推定值であり，推定值が理論值と高い精度で合致しているこ とがわかる。

\section{5 まとめ}

建築構造システムの局所的な減衰に着目し, 波動理論と伝達マト リクス法を適用することで，サブシステムの減衰を評価する「層間 伝達減衰比」を提案した。この層間伝達減衰比は減衰の型によって 周波数との関係が変化する指標であり, どのようなタイプの減衰が 支配的であるかを示す指標となりうること, また, パラメータ変動 を想定した建物モデルに対して層間伝達減衰比を求めた結果から， 変動の大小や変動箅所の数にかかわらず変動を感知できることを示 した。

また, 最上層でのホワイトノイズ加振による層間伝達減衰比の推 定手法を示した。せん断力の逐次計算や伝達マトリクスの推定に正 弦波加振時の変位态答を直接用いる手法では，サンプリング時間・ 推定精度における問題から，実用性にかけるきらいがある。そこ で, ランダム加振の観測データからコンプライアンスを推定する手 法を採用することで，サンプリング時間・推定精度における問題を 解決した。

ただし, 現状では, 提案した層間伝達減衰比だけから, 減衰の型 が未知の状況で, 減衰・剛性のどちら (あるいはその両方)に変化が 生じたかを判断するのは必ずしも簡単ではない。しかし, 層間伝達 減衰比によりあらかじめどのようなタイプの減衰が支配的であるか を特定すれば，補遗に示すように減衰・剛性の値を算出することが でき，建築構造物の振動解析・制振システム設計の指標や構造へル スモニタリングへの将来的な応用が可能になることが期待できる。

本研究は, 早稲田大学特定課題研究 (99A-228) による補助を受 けました。

\section{補遗}

減衰の型が既知の場合，それぞれの減衰の型に応じた式によって $i$ 層の堿衰 $c_{i}$ と剛性 $k_{i}$ が算出できる。 
Kelvin 型の場合，式 (5) より以下のようになる。

$$
\left\{\begin{aligned}
k_{i} & =\operatorname{Re}\left\{\frac{Q_{i-1}^{U}}{x_{i}^{U}-x_{i-1}^{U}}\right\} \\
c_{i} & =\operatorname{Im}\left\{\frac{Q_{i-1}^{U}}{x_{i}^{U}-x_{i-1}^{U}}\right\} / \omega
\end{aligned}\right.
$$

ただし， $\operatorname{Re}\{\cdot\}, \operatorname{Im}\{\cdot\}$ は，それぞれ $\{\cdot\}$ の実部，虚部を表す。 また, Maxwell 型の場合, 式(9)より以下のようになる。

$$
\left\{\begin{array}{l}
k_{i}=\left[\operatorname{Re}\left\{\frac{x_{i}^{U}-x_{i-1}^{U}}{Q_{i-1}^{U}}\right\}\right]^{-1} \\
c_{i}=\left[\omega \operatorname{Im}\left\{\frac{x_{i}^{U}-x_{i-1}^{U}}{Q_{i-1}^{U}}\right\}\right]^{-1}
\end{array}\right.
$$

\section{参考文献}

1）清水幹, 山田就康, 西谷章 : 波動理論を用いた制震構造物の各層減 衰比の同定, 日本建築学会大会学術講演論文集構造 II, pp.797-798, 1997

2) 山下大, 山田聖治, 西谷章 : 各層ごとの堿衰率評価による構造モ二 タリング, 日本建築学会大会学術講演論文集構造 II, pp.759-760, 1998

3） E.C. ペステル, F.A.レキー：マトリクス法による振動解析, ブレ イン図書出版, 1978

4）山川宏, 大西哲也：逐次伝達マトリックス法による大規模構造 物の動的応答解析, 日本機械学会論文集 (C 編), Vol.48, No.429, pp.672-681, 1982
5) 長松昭男 : モード解析入門, コロナ社, 1993

6) 背戸一登 : 動吸振器による多自由度系の制振 (第 1 報, 動吸振器の 設計理論), 日本機械学会論文集 (C 編), Vol.50, No.458, pp.19621969,1984

7) Doyle, J. F. : Wave Propagation in Strcutures : Spectral Analysis Using Fast Discrete Fourier Transforms, Second Edition, Springer-Verlag New York Inc., 1997

8) Flotow, A. H. von : Disturbance Propagation in Structural Networks, Journal of Sound and Vibration, Vol.106(3), pp.433-450, 1986

9) Mead, D.J. : A New Method of Analyzing Wave Propagation in Periodic Structures; Applications to Periodic Timoshenko Beams and Stiffened Plates, Journal of Sound and Vibration, Vol.104, pp.9-27, 1986

10) 徳岡辰雄 : 波動論, サイエンス社, 1985

11）田中信雄, 菊島義弘 : 柔軟ばりの曲げ波制御に関する研究(アクティ ブ・シンク法の提案)，日本機械学会論文集 (C 編), Vol.56, No.522, pp.351-359, 1990

12）福和伸夫, 勝倉裕, 中井正一,イグサタケル : 伝達行列法を用いた 線状周期構造物の振動特性に関する研究-1 次元連続体と集中質点 で権成される周期椿造の波動伝播特性に関する基整的考察-，日本 建勧学会構造系論文報告集, No.421, pp.101-108, 1991

13）福和伸夫, 勝倉裕, 中井正一 : 離散解析モデルにおける波動の分散性 と最適整合質量比の提示, 日本建築学会構造系論文報告集, No.433, pp.83-90, 1992

14）西谷章，山田聖治：AMD を利用した制御対象の同定に基づく $H^{\infty}$ 制振システム再設計, 日本建築学会構造系論文報告集, No.516, pp.65-71, 1999 